\title{
0030. Effect of exercise training on muscle function in a recovery model of critical illness
}

\author{
A Sigurta*, S Saeed, M Singer \\ From ESICM LIVES 2014 \\ Barcelona, Spain. 27 September - 1 October 2014
}

\section{Introduction}

Survivors of critical illness experience significant skeletal muscle weakness and physical disability, which may persist for years [1]. Early mobilization is being encouraged to improve functional outcomes [2]. Decreased mitochondrial function and altered mitochondrial biogenesis are implicated in the pathogenesis of sepsis-induced muscle dysfunction [3]. Mitochondrial biogenesis can be stimulated by physical activity [4].

\section{Objectives}

To assess the role of exercise training on muscle function and mitochondrial biogenesis in a long term rat model of critical illness and recovery.

\section{Methods}

Peritonitis was induced in male Wistar rats by i.p. injection of the fungal cell wall product, zymosan. Animals were divided into 2 groups: (i) trained animals who

underwent daily motorised treadmill sessions from day 2-14, progressively increasing treadmill speed and duration to $30 \mathrm{mins}$ at $30 \mathrm{~cm} / \mathrm{s}$; (ii) control animals.

Weight and clinical score were recorded daily. Muscle function was assessed on days 2, 7 and 14 using exercise capacity and forelimb grip strength. On day 14, animals were culled for harvesting of gastrocnemius and soleus muscle that were weighed and then used to measure (by RT-PCR) gene expression assays of the biogenesis factors, PGC-1alpha, NRF and Tfam. Results given as ratios, using HMBS as the housekeeping gene.

\section{Results}

All animals lost weight post-zymosan and gained weight thereafter, with trained animals doing so at a greater rate (Fig 1). Exercise capacity increased by approximately $50 \%$ in both groups between Day 2 and Day 7 , but was only maintained at Day 14 in trained animals. Grip strength was maintained throughout in trained

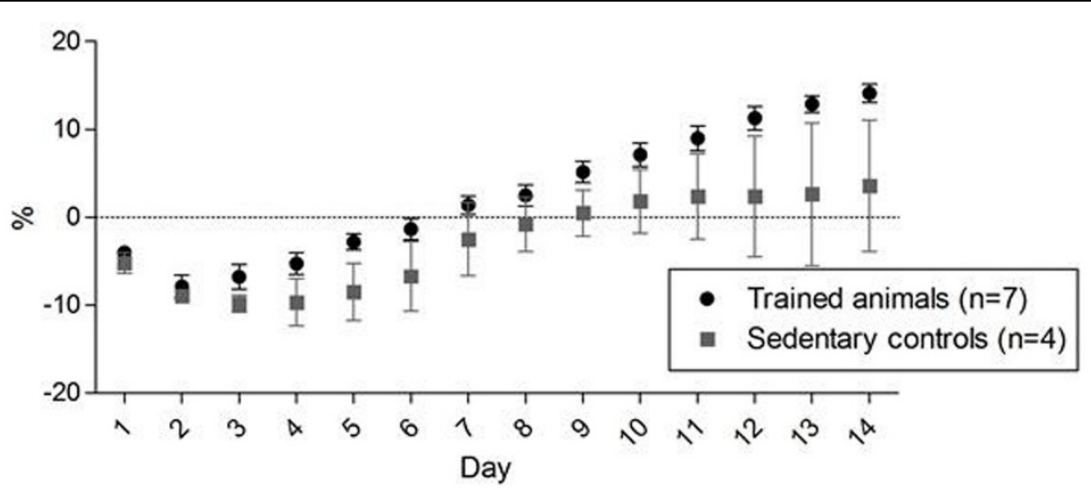

Figure 1 Changes in body weight expressed as percentage from baseline weight. Data shown as mean \pm SE. 


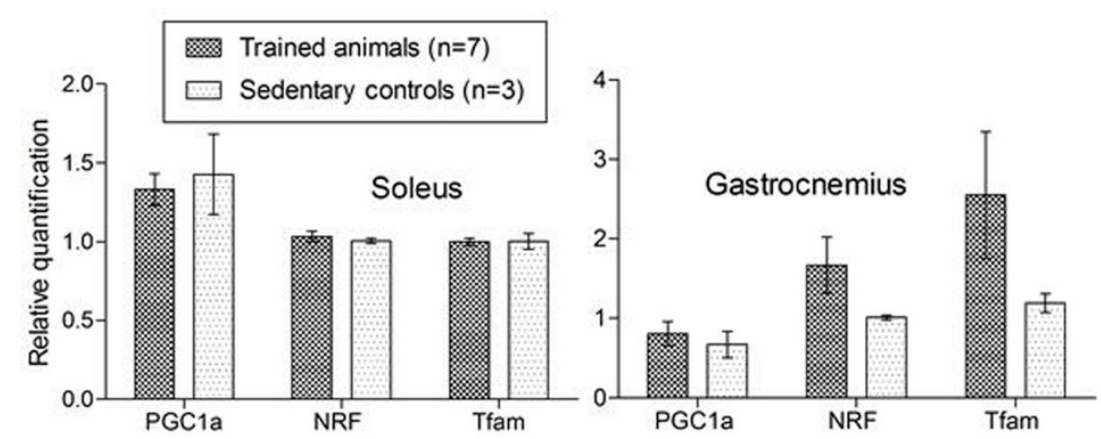

Figure 2 Real-time PCR (mean $\pm \mathrm{SE}$ ) on Day 14 soleus and gastrocnemius muscle.

animals but fell by $29.2 \pm 14 \%$ at Day 7 in controls. Tfam and NRF, but not PGC-1alpha, were higher in gastrocnemius in trained animals, but not in soleus (Fig 2).

\section{Conclusions}

Exercise training increases weight gain in this model of critical illness and recovery. Preliminary data shows improved mitochondrial biogenesis in gastrocnemius but not soleus with exercise.

Published: 26 September 2014

\section{References}

1. Herridge MS, et al: Functional disability 5 years after acute respiratory distress syndrome. N Engl J Med 2011, 364:1293-304.

2. Schweickert WD, et al: Early physical and occupational therapy in mechanically ventilated, critically ill patients: a randomised controlled trial. Lancet 2009, 373:1874-82.

3. Carré JE, et al: Survival in critical illness is associated with early activation of mitochondrial biogenesis. Am J Respir Crit Care Med 2010, 182:745-51.

4. Wang $L$, et al: Similar expression of oxidative genes after interval and continuous exercise. Med Sci Sports Exerc 2009, 41:2136-44.

doi:10.1186/2197-425X-2-S1-04

Cite this article as: Sigurta et al:: 0030. Effect of exercise training on muscle function in a recovery model of critical illness. Intensive Care Medicine Experimental 2014 2(Suppl 1):O4.

\section{Submit your manuscript to a SpringerOpen ${ }^{\circ}$ journal and benefit from:}

- Convenient online submission

- Rigorous peer review

- Immediate publication on acceptance

- Open access: articles freely available online

- High visibility within the field

- Retaining the copyright to your article

Submit your next manuscript at $>$ springeropen.com 